\title{
Systematic Review of Clinical Trials Assessing the Effectiveness of Ivy Leaf (Hedera Helix) for Acute Upper Respiratory Tract Infections
}

\author{
Felix Holzinger and Jean-François Chenot \\ Department of General Practice/Family Medicine, University Medicine Goettingen, Humboldtallee 38, 37073 Goettingen, Germany \\ Correspondence should be addressed to Jean-François Chenot, jchenot@gwdg.de
}

Received 16 May 2010; Accepted 17 August 2010

Copyright ( $) 2011$ F. Holzinger and J.-F. Chenot. This is an open access article distributed under the Creative Commons Attribution License, which permits unrestricted use, distribution, and reproduction in any medium, provided the original work is properly cited.

\begin{abstract}
Introduction. Among nonantibiotic cough remedies, herbal preparations containing extracts from leaves of ivy (Hedera helix) enjoy great popularity. Objective. A systematic review to assess the effectiveness and tolerability of ivy for acute upper respiratory tract infections (URTIs). Methods. We searched for randomized controlled trials (RCTs), nonrandomized controlled clinical trials and observational studies evaluating the efficacy of ivy preparations for acute URTIs. Study quality was assessed by the Jadad score or the EPHPP tool. Results. 10 eligible studies were identified reporting on 17463 subjects. Studies were heterogeneous in design and conduct; 2 were RCTs. Three studies evaluated a combination of ivy and thyme, 7 studies investigated monopreparations of ivy. Only one RCT $(n=360)$ investigating an ivy/thyme combination used a placebo control and showed statistically significant superiority in reducing the frequency and duration of cough. All other studies lack a placebo control and show serious methodological flaws. They all conclude that ivy extracts are effective for reducing symptoms of URTI. Conclusion. Although all studies report that ivy extracts are effective to reduce symptoms of URTI, there is no convincing evidence due to serious methodological flaws and lack of placebo controls. The combination of ivy and thyme might be more effective but needs confirmation.
\end{abstract}

\section{Introduction}

Cough is a highly prevalent condition and a common reason for consultations in general practice [1-4]. Most frequently, cough symptoms are caused by acute viral upper respiratory tract infections (URTIs) and the course is mostly benign and self-limiting, although bacterial superinfection may occur in acute bronchitis $[5,6]$. For chronic cough, important causes are chronic obstructive pulmonary disease (COPD) and asthma which are characterized by airway obstruction and hypersecretion of mucus, additionally causing symptoms like wheezing or dyspnoea.

Inappropriate use of antibiotics for viral respiratory tract infections is a significant problem causing both pathogen resistance and substantial health care expenditure without affecting the resolution of cough [7]. Therefore nonantibiotic alternative treatment options are needed. Commonly used over-the-counter drugs for acute cough in both children and adults are mucolytic agents and antitussives, which are also widely prescribed in primary care settings [8]. In the UK, cough liquids accounted for sales worth 102 million pounds in 2008 [9]. Among these nonantibiotic cough remedies, herbal preparations containing extracts from the leaves of ivy (Hedera helix L.) enjoy great popularity in many European countries [10-12]. In 2007, more than $80 \%$ of herbal expectorants prescribed in Germany comprised ivy extract and amounted to nearly 2 million prescriptions nationwide and a volume of sales exceeding 13 million Euros [10].

Ivy leaf contains saponins which are considered to have mucolytic, spasmolytic, bronchodilatory and antibacterial effects $[13,14]$. Despite widespread use of ivy leaf extracts, the effectiveness for the treatment of acute cough is not well established. Methodically strong clinical studies seem scarce despite the epidemiological and economic importance. To our knowledge, there is no comprehensive systematic review 
of the available clinical evidence. A Cochrane Review assessing over-the-counter cough medications does not cover herbal drugs [8]. Other reviews focus on effectiveness of ivy leaf extracts in asthma or COPD [12, 15-17]. Therefore, we performed a systematic review of the effectiveness and tolerability of ivy preparations for the treatment of acute URTIs in children and adults.

\section{Methods}

2.1. Data Sources. Our search included 3 electronic bibliographic databases: MEDLINE, EMBASE and the Cochrane Library. We included studies published from the respective inception of the databases until 20. December 2009. There was no language restriction. Search terms were: ivy, hedera, respiratory tract diseases, respirat*, cough, bronchitis, bronchial. The complete search algorithm with the keywords and $\mathrm{MeSH}$-terms used is available from the authors upon request. Additionally, we hand searched the bibliographies of the publications retrieved. Several manufacturer websites were also scanned manually for references.

\subsection{Study Selection}

2.2.1. Eligibility Criteria. We did not exclude specific populations or age groups. Our search included published randomized controlled trials (RCTs), controlled clinical trials (CCTs) and noncontrolled observational studies (OSs) evaluating the effectiveness and/or tolerability of medications containing ivy leaf extract for the treatment of acute URTIs including bronchitis. Studies investigating patients with a variety of other acute (e.g., pertussis, pneumonia) and chronic diseases (COPD, asthma) were excluded. However, we did not disregard studies where URTI patients represented the majority of investigated subjects or treatment results were reported separately. Ivy leaf extract could be the only ingredient in the respective drug preparation or could be combined with other herbal components. We restricted the search on studies evaluating oral or rectal administration forms. Outcome measures could be hard clinical endpoints (e.g., morbidity, mortality, health-related quality of life), surrogate values like spirometric parameters, physician's findings upon clinical examination, assessment of symptoms (e.g., cough) by either physician or patient, and undesirable side effects of treatment.

2.2.2. Screening Process. The titles and abstracts of the citations identified were screened by two independent reviewers (FH and JFC) separately using a predesigned form. Titles and abstracts that clearly did not meet the inclusion criteria regarding indication (respiratory symptoms) or intervention (drug containing ivy leaf extract) were excluded. Duplicate titles were also eliminated. For publications fulfilling the inclusion criteria or for which inclusion or exclusion could not be ascertained, we reviewed the full text. Disagreements were resolved by consensus. A list of references of excluded studies is available upon request from the authors. Figure 1 shows a detailed outline of the study selection process.
2.3. Quality Assessment and Data Extraction. For quality assessment of RCT, the Jadad scale (score 0-5) was used [18]. The Jadad scale is not designed for assessment of nonrandomized or noncontrolled studies as it covers mainly the study characteristics of blinding and attrition [18, 19]. To assess the methodological quality of CCTs and OSs we used the Quality Assessment Tool for Quantitative Studies developed by the Effective Public Health Practice Project (EPHPP, McMaster University, Ontario, Canada) $[20,21]$. Based on several component ratings (selection bias, study design, confounders, blinding, data collection methods, withdrawals), studies are given a global rating of either "strong", "moderate" or "weak". RCTs were given both a Jadad score and an EPHPP rating. Data was then extracted using a predesigned spreadsheet. These steps of critical quality appraisal and data extraction were performed independently by the two reviewers. Disagreements were resolved by consensus.

2.4. Data Analysis. The included studies were categorized according to their study design: RCT, CCT or OS. For controlled studies, the following comparisons were made: (1) ivy leaf extract versus placebo, (2) ivy leaf extract versus conventional therapy, (3) comparison of different formulations of Ivy leaf extract. For OSs findings before and after treatment are reported. Due to highly heterogeneous outcomes used by the included studies, we did not attempt to calculate pooled results.

\section{Results}

3.1. Characteristics of Included Studies. Our search identified 263 potentially relevant citations. Of these, 27 publications were retrieved for evaluation of the full text. We retained 10 studies for inclusion into the review. The studies were published between 1985 and 2009 and originated from a variety of countries (Germany $n=5$, Switzerland $n=$ 2 , Latin America $n=2$, Ukraine $n=1$ ). The studies report on a total of 17463 subjects in treatment and control groups. Three of these studies included only children, 2 studies only adults and 5 studies included both. Studies were heterogeneous in design and conduct, 2 were RCT, one was a CCT and 7 were OS. Of the 3 controlled studies, only one was placebo-controlled [22], one compared ivy leaf to a conventional expectorant (acetylcysteine) [23]. The third study compared two different syrup formulations containing ivy leaf extract [24]. Most studies investigated mono-preparations of ivy leaf extract, but 3 studies tested a mixture of ivy leaf and thyme extract $[22,25,26]$. One of these used a randomized controlled design [22].

The studies included patients with cough due to URTIs including acute bronchitis. Some studies included few patients with chronic bronchitis [26, 27], or the authors did not differentiate distinctly between acute disease and acute exacerbations of chronic disease [27, 28]. One study included COPD and pertussis patients, but reported the results separately [29]. The outcomes assessed by the studies were heterogeneous. Studies reported assessment of URTI 


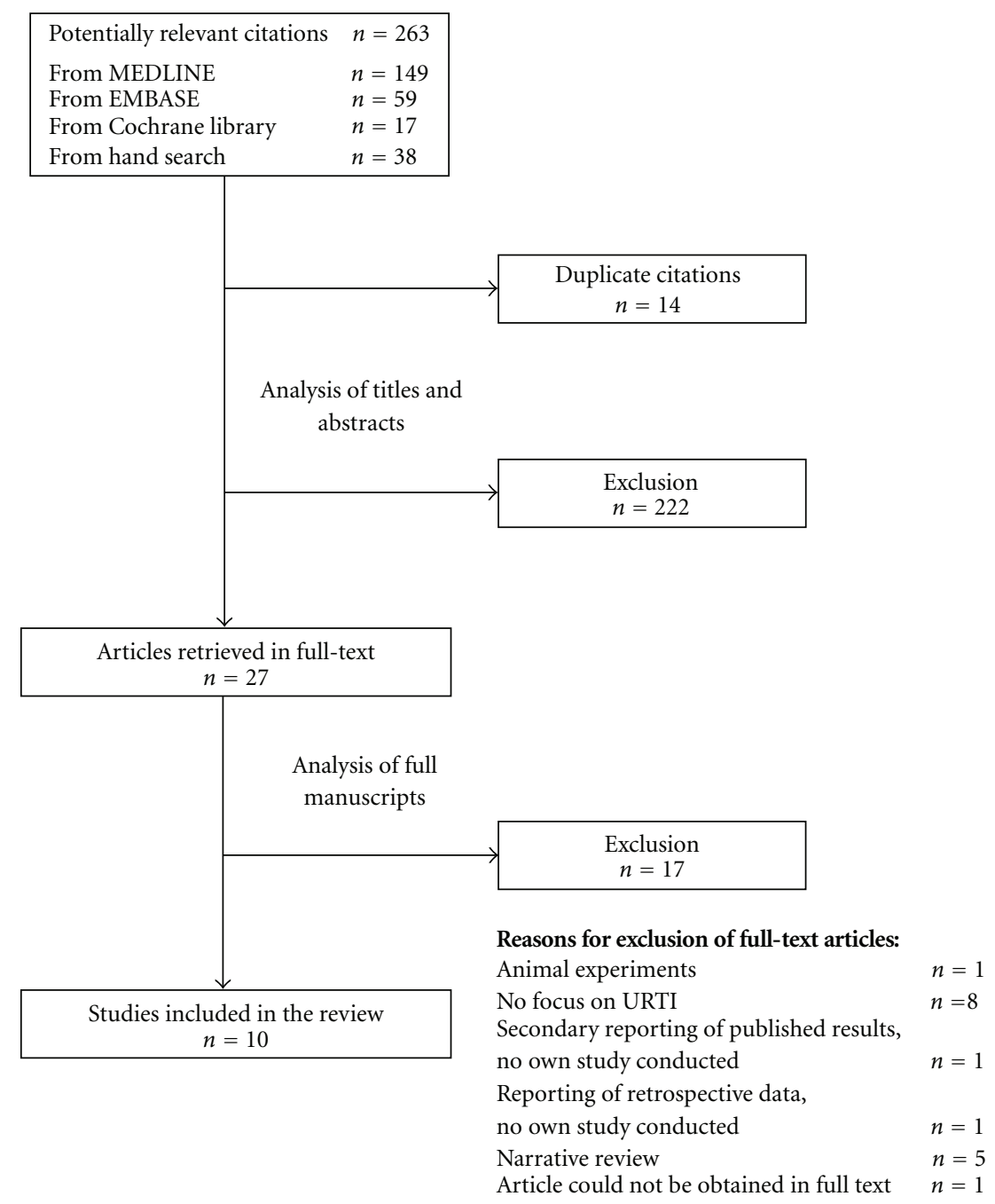

Figure 1: Study selection process.

symptoms by the treating physician or results of physical examination. Symptoms assessed varied (e.g., urge to cough, frequency of coughing, quality and quantity of sputum, shortness of breath, auscultation results). Symptom severity was measured by a variety of instruments. Two studies [22, 26] used the BSS (bronchitis severity score) scale. Several studies mainly reported percentages of improvement or cure of symptoms after a certain treatment period. Two studies additionally reported a global self-assessment by patients $[25,30]$. One study measured and reported spirometric parameters [23]. An overview of the characteristics of the studies is given in Table 1.

Only one RCT met the standards of good clinical practice with regard to conduct and reporting, sample size calculation and an appropriate statistical analysis and was rated with a Jadad score of 5 ("strong") [22]. All other studies, including the second RCT [24] had serious flaws. It was often impossible to discern whether the participants were representative of the target population of unselected URTI patients. The studies did not describe the selection process or relied on self-selected participants (selection bias). Confounding was a problem in a large number of studies as well. Many studies allowed concomitant use of other cough remedies or even antibiotics or steroids [23, 29, 30] or did not address this factor at all [26]. Presence of concomitant diseases (e.g., cardiovascular) was not an exclusion criterion [23, 25, 29] or not assessed [26, 30]. Dropout rates or reasons for dropout were frequently not reported [2731]. No intention-to-treat analysis was reported. Statistical analysis was performed by only few studies [22-24, 27], most studies just describe the results. One study reporting $P$-values does not mention the statistical test performed [23]. Table 2 shows details of the quality assessment.

The reported results are shown in Table 3 and summarized in the following sections.

3.2. Ivy Leaf Extract versus Placebo. No studies comparing ivy leaf mono-preparations for the treatment of URTIs to a placebo control could be identified. One German RCT 


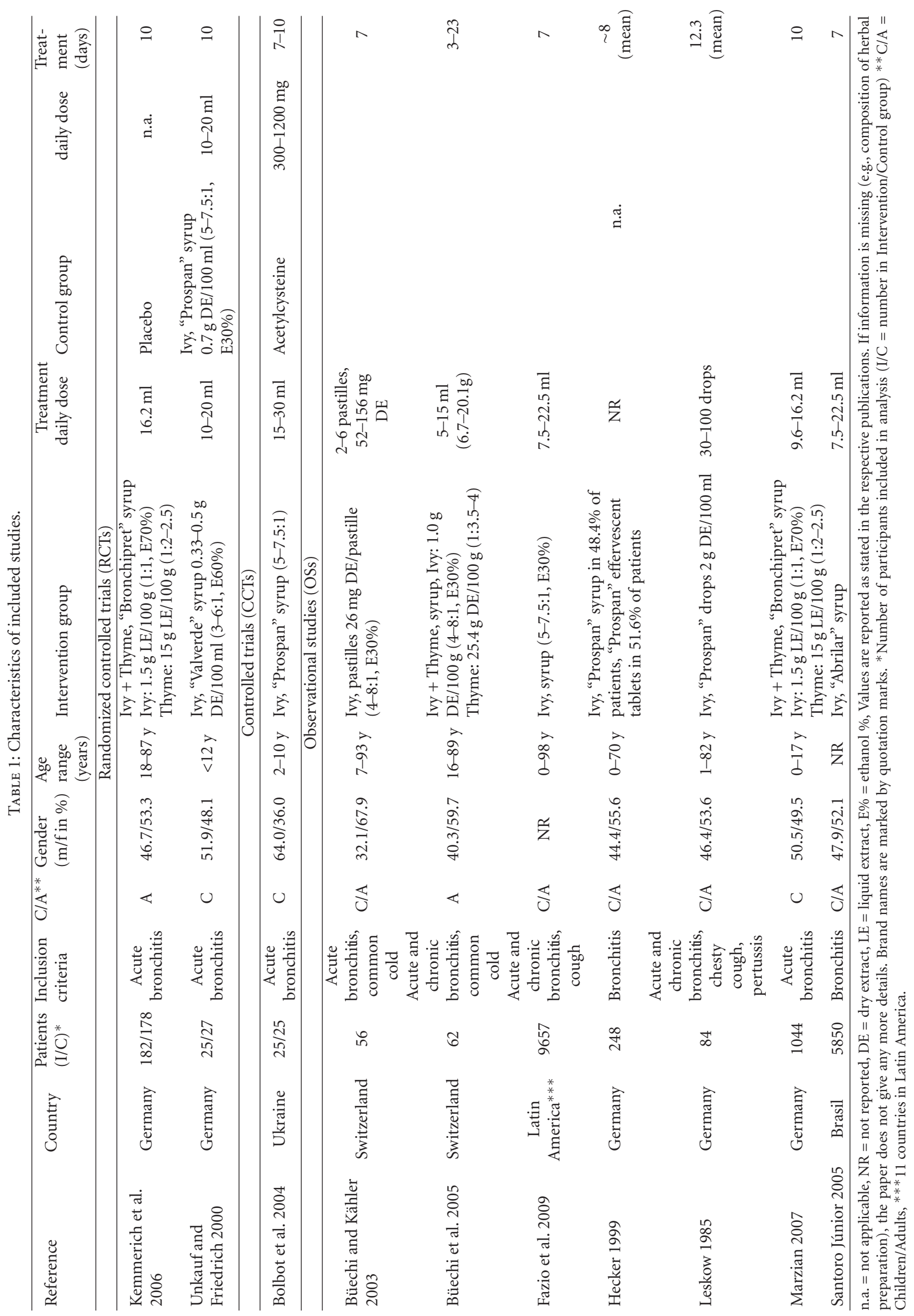


TABLE 2: Quality assessment of included studies.

\begin{tabular}{|c|c|c|c|c|c|c|c|c|}
\hline \multirow{2}{*}{ Reference } & \multicolumn{6}{|c|}{ EPHPP Section ratings (strong/moderate/weak) } & \multirow{2}{*}{$\begin{array}{l}\text { Global } \\
\text { rating }\end{array}$} & \multirow{2}{*}{$\begin{array}{l}\text { Jadad } \\
\text { score }(0-5)\end{array}$} \\
\hline & $\begin{array}{l}\text { Selection } \\
\text { bias }\end{array}$ & $\begin{array}{l}\text { Study } \\
\text { design }\end{array}$ & Confounders & Blinding & $\begin{array}{c}\text { Data } \\
\text { collection }\end{array}$ & Withdrawals & & \\
\hline \multicolumn{9}{|c|}{ Randomized controlled trials (RCTs) } \\
\hline $\begin{array}{l}\text { Kemmerich } \\
\text { et al. } 2006\end{array}$ & moderate & strong & strong & strong & weak & strong & strong & 5 \\
\hline $\begin{array}{l}\text { Unkauf and } \\
\text { Friedrich } \\
2000\end{array}$ & weak & strong & moderate & weak & weak & strong & weak & 2 \\
\hline \multicolumn{9}{|c|}{ Controlled trials (CCTs) } \\
\hline $\begin{array}{l}\text { Bolbot et al. } \\
2004\end{array}$ & moderate & moderate & weak & weak & moderate & strong & weak & n.a. \\
\hline \multicolumn{9}{|c|}{ Observational studies (OSs) } \\
\hline $\begin{array}{l}\text { Büechi and } \\
\text { Kähler } 2003\end{array}$ & weak & moderate & weak & weak & weak & weak & weak & \\
\hline $\begin{array}{l}\text { Büechi et al. } \\
2005\end{array}$ & weak & moderate & weak & weak & weak & strong & weak & \\
\hline $\begin{array}{l}\text { Fazio et al. } \\
2009\end{array}$ & moderate & moderate & weak & weak & weak & strong & weak & \\
\hline Hecker 1999 & weak & moderate & weak & weak & weak & weak & weak & n.a. \\
\hline Leskow 1985 & weak & moderate & moderate & weak & weak & weak & weak & \\
\hline Marzian 2007 & moderate & moderate & weak & weak & weak & weak & weak & \\
\hline $\begin{array}{l}\text { Santoro } \\
\text { Júnior } 2005\end{array}$ & moderate & moderate & moderate & weak & weak & strong & weak & \\
\hline
\end{tabular}

n.a. = not applicable.

compared ivy/thyme to placebo [22]. This trial included 370 adult patients which were treated for 10 days with a syrup (ivy $1.5 \mathrm{~g}$ liquid extract/100 g $1: 1$, ethanol 70\%, thyme $15 \mathrm{~g}$ liquid extract/100 g $1: 2-2.5)$. Outcome measures were the frequency of coughing fits, the time to a relative $50 \%$ reduction in coughing fits, the BSS and overall response rate. All outcomes assessed were significantly better in the intervention group.

\subsection{Ivy Leaf Extract versus Conventional Expectorant Therapy.} One Ukrainian study group conducted a CCT comparing ivy to acetylcysteine in acute bronchitis [23]. A total of 50 children were treated for 7-10 days with either syrup containing ivy leaf extract or 300-1200 mg of acetylcysteine. Symptoms (cough, sputum, shortness of breath) were improved in both groups after treatment. Compared to the baseline, both treatment groups showed improved spirometric values (FVC, FEV1, PEF) after treatment. Spirometric parameters were significantly better in the group receiving the ivy formulation. The authors conclude that ivy leaf has bronchodilatory as well as mucolytic effects.

3.4. Comparison of Different Formulations of Ivy. One of the two RCTs included in this systematic review compared two different syrup preparations of ivy leaf extract $(0.33-0.5 \mathrm{~g}$

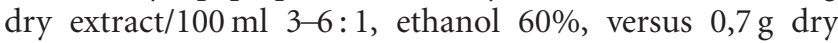
extract/100 ml 5-7.5:1, ethanol 30\%) [24]. A total of 52 patients were treated for 10 days after randomization, severity of cough symptoms was assessed. No significant difference was observed.

3.5. Observational Studies. Five noncontrolled OSs investigated ivy mono-preparations [27-31] and 2 OSs investigated ivy/thyme combinations $[25,26]$. These studies included a large number of patients, the 2 largest studies (both conducted in Latin America) [27, 31] together reporting on over 15000 subjects. Most of the OSs were postmarketing surveillance-studies sponsored by the manufacturers. Symptoms were assessed at baseline and after treatment for 7 to 10 days, mostly by the investigating physicians. Different symptoms (e.g., cough, expectoration, shortness of breath) were assessed on a variety of scales. Two studies used a four-level Likert scale [28, 30]. Most studies observed improvement or cure after treatment in more than $90 \%$. Global efficacy was rated as good or very good by physicians in $77-86 \%[25,28,30]$. One study assessing auscultation findings reported significantly less rales after treatment compared to baseline [27].

3.6. Adverse Events. All but one publication studied adverse events as an outcome parameter [24]. Side effects were observed in $0 \%$ [30] to $3.8 \%$ [22]. Symptoms were mostly mild and transient abdominal discomfort, diarrhoea or nausea. One study reported allergic reactions in $0.1 \%$ of patients (10 cases in a large study population of over 10000 patients) [31]. In another study one patient out of $248(0.4 \%)$ who was concomitantly treated with paracetamol developed 
TABLe 3: Summary of the results of included studies.

\begin{tabular}{|c|c|c|c|c|c|c|c|}
\hline \multirow{2}{*}{ Reference } & \multirow{2}{*}{ Diagnosis } & \multicolumn{2}{|c|}{ Treatment } & \multirow{2}{*}{$\begin{array}{l}\text { Outcomes assessed } \\
\text { (selection)* }\end{array}$} & \multicolumn{2}{|c|}{ Results } & \multirow{2}{*}{ Statistics** } \\
\hline & & $\begin{array}{l}\text { Intervention } \\
\text { group }\end{array}$ & Control group & & Intervention group & Control group & \\
\hline \multicolumn{8}{|c|}{ Ivy leaf extract versus placebo } \\
\hline
\end{tabular}

\begin{tabular}{|c|c|c|c|c|c|c|c|}
\hline \multirow{4}{*}{$\begin{array}{l}\text { Kemmerich } \\
\text { et al. } 2006\end{array}$} & \multirow{4}{*}{$\begin{array}{l}\text { Acute } \\
\text { bronchitis }\end{array}$} & \multirow{4}{*}{$\begin{array}{l}\text { Ivy + } \\
\text { Thyme } \\
\text { (syrup) }\end{array}$} & \multirow{4}{*}{ Placebo } & \multirow{4}{*}{$\begin{array}{l}\text { Change in frequency } \\
\text { of coughing fits } \\
\text { (relative reduction), } \\
\text { time to cessation of } \\
\text { fits, Bronchitis } \\
\text { severity score (BSS), } \\
\text { Response to } \\
\text { treatment (AD) }\end{array}$} & \multirow{4}{*}{$\begin{array}{l}\text { Frequency of } \\
\text { coughing fits } \downarrow 77.6 \% \text {, } \\
\text { Time to a } 50 \% \\
\text { reduction in fits } 6 \mathrm{~d}, \\
\text { BSS } \downarrow(8.2 \rightarrow 1.6), \\
\text { Response rate } 96.2 \%\end{array}$} & \multirow{4}{*}{$\begin{array}{l}\text { Frequency of } \\
\text { coughing fits } \downarrow 55.9 \% \text {, } \\
\text { Time to a } 50 \% \\
\text { reduction in fits } 8 \mathrm{~d} \text {, } \\
\text { BSS } \downarrow(8.3 \rightarrow 3.3), \\
\text { Response rate } 74.7 \%\end{array}$} & \multirow{2}{*}{$\begin{array}{l}P<.0001 \\
P<.0001\end{array}$} \\
\hline & & & & & & & \\
\hline & & & & & & & $P<.0001$ \\
\hline & & & & & & & $P<.0001$ \\
\hline
\end{tabular}

Ivy leaf extract versus conventional expectorant therapy

\begin{tabular}{|c|c|c|c|c|c|c|c|}
\hline $\begin{array}{l}\text { Bolbot et al. } \\
2004\end{array}$ & $\begin{array}{l}\text { Acute } \\
\text { bronchitis }\end{array}$ & Ivy (syrup) & Acetylcysteine & $\begin{array}{l}\text { FVC, FEV1, PEF, } \\
\text { Change in symptoms } \\
\text { cough frequency, } \\
\text { sputum, shortness of } \\
\text { breath, respiratory } \\
\text { pain, Global } \\
\text { assessment of efficacy } \\
\text { (based on symptoms) } \\
\text { (AD) }\end{array}$ & $\begin{array}{l}\text { FVC } \uparrow \\
\text { FEV } 1 \uparrow \\
\text { PEF } \uparrow \\
\text { Global efficacy rated } \\
\text { as very good in } 40.0 \%\end{array}$ & $\begin{array}{l}\text { FVC } \uparrow \\
\text { FEV } 1 \uparrow \\
\text { PEF } \uparrow \\
\text { Global efficacy rated } \\
\text { as very good in } 12.5 \%\end{array}$ & $\begin{array}{l}\mathrm{s} \\
\mathrm{s} \\
\mathrm{s}\end{array}$ \\
\hline \multicolumn{8}{|c|}{ Comparison of different formulations of ivy } \\
\hline $\begin{array}{l}\text { Unkauf and } \\
\text { Friedrich } \\
2000\end{array}$ & $\begin{array}{l}\text { Acute } \\
\text { bronchitis }\end{array}$ & Ivy (syrup) & Ivy (syrup) & $\begin{array}{l}\text { Severity of bronchitis } \\
\text { assessed on visual } \\
\text { analogue scale (AD), } \\
\text { Frequency and quality } \\
\text { of cough }\end{array}$ & $\begin{array}{l}\text { Severity } \downarrow \text { (on scale } \downarrow \\
67.3 \mathrm{~mm} \text { ) } \\
\text { After treatment } \\
26.9 \% \text { without } \\
\text { bronchitis }\end{array}$ & $\begin{array}{l}\text { Severity } \downarrow \text { (on scale } \downarrow \\
64.2 \mathrm{~mm} \text { ) } \\
\text { After treatment } \\
36.5 \% \text { without } \\
\text { bronchitis }\end{array}$ & $\begin{array}{l}P=.0031 \\
\text { for } \\
\text { equivalence } \\
\text { ns }\end{array}$ \\
\hline \multicolumn{8}{|c|}{ Observational studies (OSs) } \\
\hline $\begin{array}{l}\text { Büechi and } \\
\text { Kähler } 2003\end{array}$ & $\begin{array}{l}\text { Acute } \\
\text { bronchitis, } \\
\text { common } \\
\text { cold }\end{array}$ & $\begin{array}{l}\text { Ivy } \\
\text { (pastilles) }\end{array}$ & n.a. & $\begin{array}{l}\text { Change in symptoms } \\
\text { urge to cough and } \\
\text { sputum quantity on a } \\
\text { scale (1-4) (AD), } \\
\text { Global assessment of } \\
\text { efficacy (AD, AP) }\end{array}$ & $\begin{array}{l}\text { Urge to cough } \downarrow \\
(2.7 \rightarrow 1.3) \\
\text { Sputum quantity } \downarrow \\
(1.5 \rightarrow 1.1) \\
\text { Efficacy rated as very } \\
\text { good or good in } 78 \% \\
(\mathrm{AD}) \text { and } 77 \%(\mathrm{AP})\end{array}$ & n.a. & no statistics \\
\hline $\begin{array}{l}\text { Büechi et al. } \\
2005\end{array}$ & $\begin{array}{l}\text { Acute and } \\
\text { chronic } \\
\text { bronchitis, } \\
\text { common } \\
\text { cold }\end{array}$ & $\begin{array}{l}\text { Ivy + } \\
\text { Thyme } \\
\text { (syrup) }\end{array}$ & n.a. & $\begin{array}{l}\text { Change in symptoms } \\
\text { urge to cough, } \\
\text { sputum quantity, } \\
\text { sputum consistency, } \\
\text { ease of expectoration } \\
\text { on a scale (1-4), } \\
\text { Global assessment of } \\
\text { efficacy (AD, AP) }\end{array}$ & $\begin{array}{l}\text { Change of median } \\
\text { symptom score for } \\
\text { urge to cough, } \\
\text { sputum consistency } \\
\text { and ease of } \\
\text { expectoration } 3 \rightarrow 1 \text {, } \\
\text { for sputum quantity } \\
2 \rightarrow 1, \text { Efficacy rated } \\
\text { as very good or good } \\
\text { in } 86 \%(A D) \text { and } \\
90 \%(A P)\end{array}$ & n.a. & no statistics \\
\hline $\begin{array}{l}\text { Fazio et al. } \\
2009\end{array}$ & $\begin{array}{l}\text { Acute and } \\
\text { chronic } \\
\text { bronchitis, } \\
\text { cough }\end{array}$ & Ivy (syrup) & n.a. & $\begin{array}{l}\text { Change in symptoms } \\
\text { cough, expectoration, } \\
\text { shortness of breath, } \\
\text { respiratory pain (AD) }\end{array}$ & $\begin{array}{l}\text { Improvement or cure } \\
\text { for cough in } 93.4 \% \text {, } \\
\text { expectoration } 92.9 \% \text {, } \\
\text { shortness of breath } \\
91.2 \% \text {, pain } 90.8 \%\end{array}$ & n.a. & no statistics \\
\hline
\end{tabular}


Table 3: Continued.

\begin{tabular}{|c|c|c|c|c|c|c|c|}
\hline \multirow{2}{*}{ Reference } & \multirow{2}{*}{ Diagnosis } & \multicolumn{2}{|c|}{ Treatment } & \multirow{2}{*}{$\begin{array}{l}\text { Outcomes assessed } \\
\text { (selection)* }\end{array}$} & \multicolumn{2}{|c|}{ Results } & \multirow{2}{*}{ Statistics** } \\
\hline & & $\begin{array}{l}\text { Intervention } \\
\text { group }\end{array}$ & Control group & & Intervention group & Control group & \\
\hline Hecker 1999 & Bronchitis & Ivy (syrup) & n.a. & $\begin{array}{l}\text { Change in symptoms } \\
\text { cough, expectoration, } \\
\text { shortness of breath, } \\
\text { respiratory pain on a } \\
\text { scale (1-4) (AD), } \\
\text { Global assessment of } \\
\text { efficacy (AD) }\end{array}$ & $\begin{array}{l}\text { Improvement or cure } \\
\text { for cough in } 91.3 \% \text {, } \\
\text { expectoration } 87.5 \% \text {, } \\
\text { shortness of breath } \\
57.7 \% \text {, pain } 60.9 \% \text {, } \\
\text { Efficacy rated as very } \\
\text { good or good in } 86 \%\end{array}$ & n.a. & no statistics \\
\hline Leskow 1985 & $\begin{array}{l}\text { Acute and } \\
\text { chronic } \\
\text { bronchitis, } \\
\text { chesty } \\
\text { cough, } \\
\text { pertussis }\end{array}$ & Ivy (drops) & n.a. & $\begin{array}{l}\text { Change in symptoms } \\
\text { cough, expectoration, } \\
\text { shortness of breath } \\
\text { (AD) }\end{array}$ & $\begin{array}{l}\text { Improvement or cure } \\
\text { for cough in } 96.4 \% \text {, } \\
\text { expectoration } 100 \% \text {, } \\
\text { shortness of breath } \\
100 \%\end{array}$ & n.a. & no statistics \\
\hline $\begin{array}{l}\text { Marzian } \\
2007\end{array}$ & $\begin{array}{l}\text { Acute } \\
\text { bronchitis }\end{array}$ & $\begin{array}{l}\text { Ivy+Thyme } \\
\text { (syrup) }\end{array}$ & n.a. & $\begin{array}{l}\text { Change in frequency } \\
\text { of coughing fits, } \\
\text { Bronchitis severity } \\
\text { score } \\
\text { (BSS),Improvement } \\
\text { yes/no (AD) }\end{array}$ & $\begin{array}{l}\text { Coughing fits } \downarrow \\
(25.1 / \mathrm{d} \rightarrow 4.7 / \mathrm{d}), \\
\text { BSS } \downarrow(8.9 \rightarrow 1.2) \text {, } \\
\text { Improvement or cure } \\
\text { in } 94 \%\end{array}$ & n.a. & no statistics \\
\hline $\begin{array}{l}\text { Santoro } \\
\text { Júnior } 2005\end{array}$ & Bronchitis & Ivy (syrup) & n.a. & $\begin{array}{l}\text { Change in symptoms } \\
\text { cough and shortness } \\
\text { of breath, } \\
\text { Auscultation results } \\
\text { (AD) }\end{array}$ & $\begin{array}{l}\text { Cough } \downarrow(98.8 \% \rightarrow \\
5.4 \% \text { of patients), } \\
\text { shortness of breath } \downarrow \\
\text { Auscultation: rales } \downarrow\end{array}$ & n.a. & $\mathrm{s}$ \\
\hline
\end{tabular}

n.a. = not applicable, $\mathrm{ns}=$ not statistically significant, $\mathrm{s}=$ statistically significant, FVC = forced vital capacity, PEF $=$ peak expiratory flow, FEV1 = forced expiratory volume in one second, $\mathrm{AD}=$ assessment by doctor, $\mathrm{AP}=$ assessment by patient, * only outcome parameters reported in a manner allowing comparison between groups are listed (RCT/CCT), for OS: selected relevant outcomes. $* *$ if reported: $P$-value for intervention compared to control. For OS: $P$-value for baseline compared to after treatment.

an allergic skin rash [28]. Severe or fatal adverse events were not reported. In the RCT comparing an ivy/thyme preparation to placebo [22], rates for frequency of observed side effects were similar in the treatment $(3.8 \%)$ and placebo (4.5\%) group.

\section{Discussion}

4.1. Effectiveness. All studies reviewed concluded that ivy leaf extract is effective for the treatment of URTIs. After 7 to 10 days of treatment, symptoms like cough or expectoration are improved or cured in a large majority of patients. It has to be noted that only one placebo-controlled RCT could be retrieved. This trial showed superior results as to symptom relief and speed of recovery in the intervention group treated with a combination drug of ivy and thyme extract [22].

For ivy mono-preparations, sound evidence remains scarce. All studies investigating a mono-preparation of ivy extract lacked a placebo control. Only one study with severe methodological flaws compared ivy to acetylcysteine [23]. The remaining observational studies all observed an improvement of URTI symptoms in the course of treatment. Although the authors of these studies claim to have established effectiveness, this conclusions are not warranted since the natural course of URTIs is usually benign and selflimiting. Uncomplicated acute bronchitis usually presents with a phase of variable constitutional symptoms that lasts for one to five days, followed by cough and phlegm production lasting for one to 3 weeks, whereas cough lasting for more than 21 days can be defined as subacute or chronic and requires further diagnostic workup [32]. A review of the regression of symptoms in children with acute cough observed that after 5 to 8 days, symptoms were improved or gone in $50-75 \%$ of patients or patients were assessed as recovered by their physicians [33]. After one week, cough was resolved in about 50\%. Improvement rates shown in the Hedera helix studies included in this review tend to be higher, often exceeding 90\% [28, 29, 31]. However, these recovery rates can not serve as direct comparison because many other confounders (comedication, comorbidity) affecting the outcome have to be considered. Therefore, studies using placebo controls are indispensable to establish effectiveness.

Only for the combination of ivy and thyme evidence for effectiveness of faster recovery could be found [22]. A $50 \%$ reduction in coughing fits was reached 2 days earlier in the treatment group, which can be considered a clinically relevant improvement. It remains unclear if the observed effect can be attributed to the action of thyme or the combination. Although thyme is traditionally used for 
URTIs, we found no clinical trials or a systematic review evaluating the effectiveness of mono-preparations of thyme. Blinding might have been a problem since the producing placebos with comparable taste and smell for oral herbal therapies is difficult.

4.2. Tolerability. The benefits of any treatment have to be weighted against potential harms. As severe adverse events were not reported with more than 17000 subjects treated, there is considerable evidence for the safety of hedera helix. In the placebo-controlled study, only minimal differences in adverse events between verum and placebo group were observed [22]. Allergic reactions were reported in under $0.5 \%$ of cases with no cases of severe anaphylaxis mentioned in any study. This is especially important regarding the fact that hedera helix has been reported to cause allergic contact dermatitis [34, 35] and rarely even occupational asthma in gardeners exposed to the leaves [36].

4.3. Strengths and Limitations. We comprehensively searched medical databases with no restrictions regarding time or language. An extensive hand-searching process added further studies for review, so we can be confident as to the completeness of the evidence identified. However, several limitations have to be taken into account. Firstly, the databases covered mainly focus on the American and European literature. As hedera helix products are also marketed in the Middle East and East Asia, some studies published in local journals and not listed in MEDLINE or EMBASE could have been missed. Furthermore, a large number of included studies was sponsored by the manufacturers $[22,25-29,31]$ or funding was not reported. Studies sponsored by the manufacturer are prone to publication bias [37]. One study was published in a section of a phytotherapy journal in which articles originating from pharmaceutical companies could be published without any editing or review [29].

A quantitative synthesis of the data gathered from the studies (e.g., meta-analysis) was not possible due to low-quality data and great heterogeneity in study designs and outcomes. Future trials will require a consensus on a standard for measuring symptom relief in URTIs.

\section{Conclusion}

Although many studies conclude that ivy extracts are effective to reduce symptoms of acute URTIs, their effectiveness is not established beyond reasonable doubt. The studies reviewed show serious methodological flaws and lack placebo controls. Therefore their findings must be interpreted with due caution. For a combination of ivy and thyme, effectiveness has been demonstrated in one RCT, however these findings need to be confirmed. Ivy extracts are well tolerated, no serious adverse events were reported. It has to be taken into account that other popular cough medications, for example, acetylcysteine [38] and other OTC antitussives and decongestants [8], also lack a sound evidence base. Reducing the use of antibiotics for uncomplicated URTIs is an important public health goal [39]. Given a high desire for treatment, abandoning the use of non-evidencebased cough remedies might cause a surge in the prescription of antibiotics, which poses the risks of serious adverse events and the development of antibiotic resistance. Considering the popularity of ivy preparations and the considerable expenditure for such remedies, further rigorously designed randomized controlled trials are necessary.

\section{Conflict of Interest Statement}

The authors declare that they have no proprietary, financial, professional or other personal interest of any nature or kind in any product, service and/or company that could be construed as influencing the position presented in this paper.

\section{Funding}

This work was not supported by any external funding.

\section{Contribution of the Authors}

The literature search was done by F. Holzinger, selection and appraisal of studies and writing of the manuscript was done by F. Holzinger and J. F. Chenot.

\section{Acknowledgment}

The authors are grateful to Professor Michael M. Kochen for helpful advice.

\section{References}

[1] A. McCormick, D. Fleming, and J. Charlton, Morbidity Statistics from General Practice. Fourth National Study 19911992, HMSO, London, UK, 1995.

[2] E. Hak, M. M. Rovers, M. M. Kuyvenhoven, F. G. Schellevis, and T. J. Verheij, "Incidence of GP-diagnosed respiratory tract infections according to age, gender and high-risk comorbidity: the Second Dutch National Survey of General Practice," Family practice, vol. 23, no. 3, pp. 291-294, 2006.

[3] J. Charles, Y. Pan, and H. Britt, "Trends in childhood illness and treatment in Australian general practice, 1971-2001," Medical Journal of Australia, vol. 180, no. 5, pp. 216-219, 2004.

[4] K. F. Chung and I. D. Pavord, "Prevalence, pathogenesis, and causes of chronic cough," The Lancet, vol. 371, no. 9621, pp. 1364-1374, 2008.

[5] R. Gonzales, J. G. Bartlett, R. E. Besser, J. M. Hickner, J. R. Hoffman, and M. A. Sande, "Principles of appropriate antibiotic use for treatment of nonspecific upper respiratory tract infections in adults: background," Annals of Internal Medicine, vol. 134, no. 6, pp. 490-494, 2001.

[6] R. S. Irwin and J. M. Madison, "The diagnosis and treatment of cough," New England Journal of Medicine, vol. 343, no. 23, pp. 1715-1721, 2000.

[7] T. Fahey, N. Stocks, and T. Thomas, "Quantitative systematic review of randomised controlled trials comparing antibiotic with placebo for acute cough in adults," British Medical Journal, vol. 316, no. 7135, pp. 906-910, 1998. 
[8] S. M. Smith, K. Schroeder, and T. Fahey, "Over-the-counter medications for acute cough in children and adults in ambulatory settings," Cochrane Database of Systematic Reviews, no. 1, Article ID CD001831, 2008.

[9] Proprietary Association of Great Britain, PAGB Annual Review 2009, PAGB, London, UK, 2009.

[10] V. Coca and K. Nink, "Supplementary statistical overview," in Pharmaceutical Prescription Report, U. Schwabe and D. Paffrath, Eds., pp. 963-1071, Springer, Heidelberg, Germany, 2008 (German).

[11] G. Glaeske, C. Schicktanz, and K. Janhsen, "GEK Pharmaceutical report," GEK Statutory health insurance, 2008 (German).

[12] R. Guo, M. H. Pittler, and E. Ernst, "Herbal medicines for the treatmet of COPD: a systematic review," European Respiratory Journal, vol. 28, no. 2, pp. 330-338, 2006.

[13] A. Sieben, L. Prenner, T. Sorkalla et al., " $\alpha$-Hederin, but not hederacoside $\mathrm{c}$ and hederagenin from Hedera helix, affects the binding behavior, dynamics, and regulation of $\beta_{2}$ - adrenergic receptors," Biochemistry, vol. 48, no. 15, pp. 3477-3482, 2009.

[14] A. Gepdiremen, V. Mshvildadze, H. Süleyman, and R. Elias, "Acute anti-inflammatory activity of four saponins isolated from ivy: alpha-hederin, hederasaponin-C, hederacolchiside$\mathrm{E}$ and hederacolchiside- $\mathrm{F}$ in carrageenan-induced rat paw edema," Phytomedicine, vol. 12, no. 6-7, pp. 440-444, 2005.

[15] E. Arnold, C. E. Clark, T. J. Lasserson, and T. Wu, "Herbal interventions for chronic asthma in adults and children," Cochrane Database of Systematic Reviews, no. 1, Article ID CD005989, 2008.

[16] A. Huntley and E. Ernst, "Herbal medicines for asthma: a systematic review," Thorax, vol. 55, no. 11, pp. 925-929, 2000.

[17] D. Hofmann, M. Hecker, and A. Völp, "Efficacy of dry extract of ivy leaves in children with bronchial asthma-a review of randomized controlled trials," Phytomedicine, vol. 10, no. 2-3, pp. 213-220, 2003.

[18] A. R. Jadad, R. A. Moore, D. Carroll et al., "Assessing the quality of reports of randomized clinical trials: is blinding necessary?" Controlled Clinical Trials, vol. 17, no. 1, pp. 1-12, 1996.

[19] S. L. Norris and D. Atkins, "Challenges in using nonrandomized studies in systematic reviews of treatment interventions," Annals of Internal Medicine, vol. 142, no. 12, pp. 1112-1119, 2005.

[20] "Quality Assessment Tool for Quantitative Studies," December 2009, http://www.ephpp.ca/tools.html.

[21] B. H. Thomas, D. Ciliska, M. Dobbins, and S. Micucci, "A process for systematically reviewing the literature: providing the research evidence for public health nursing interventions," Worldviews on Evidence-Based Nursing, vol. 1, no. 3, pp. 176184, 2004.

[22] B. Kemmerich, R. Eberhardt, and H. Stammer, "Efficacy and tolerability of a fluid extract combination of thyme herb and ivy leaves and matched placebo in adults suffering from acute bronchitis with productive cough: a prospective, double-blind, placebo-controlled clinical trial," Arzneimittel-Forschung, vol. 56, no. 9, pp. 652-660, 2006 (German).

[23] Y. Bolbot, E. Prokhorov, S. Mokia, and A. Yurtseva, "Comparing the efficacy and safety of high-concentrate (5-7.5:1) ivy leaves extract and acetylcysteine for treatment of children with acute bronchitis," Liky Ukrainy, vol. 11, 2004 (Ukrainian).

[24] M. Unkauf and M. Friedrich, "Bronchitis in children-clinical study of dry extract of ivy," Der Bayerische Internist, vol. 4, pp. 2-4, 2000 (German).

[25] S. Büechi, R. Vögelin, M. Mennet-Von Eiff, M. Ramos, and J. Melzer, "Open trial to assess aspects of safety and efficacy of a combined herbal cough syrup with ivy and thyme," Forschende Komplementarmedizin und Klassische Naturheilkunde, vol. 12, no. 6, pp. 328-332, 2005.

[26] O. Marzian, "Treatment of acute bronchitis in children and adolescents. Non-interventional postmarketing surveillance study confirms the benefit and safety of a syrup made of extracts from thyme and ivy leaves," MMW-Fortschritte der Medizin, vol. 149, no. 27-28, pp. 69-74, 2007 (German).

[27] M. Santoro Jr., "Evaluation of Hedera helix as an expectorant in patients with productive cough. A multicenter study over 5850 patients," Revista Brasileira de Medicina, vol. 62, no. 1-2, pp. 47-52, 2005 (Portuguese).

[28] M. Hecker, "Efficacy and tolerance of ivy extract in patients suffering from respiratory tract diseases," Natural Medicine, vol. 14, pp. 28-33, 1999 (German).

[29] P. Leskow, "Treatment of bronchial diseases with the phytotherapeutic drug Prospan," Zschr Phytother, vol. 6, pp. 6164, 1985 (German).

[30] S. Büechi and D. Kähler, "Ivy (hedera helix) for respiratory diseases. An open clinical study with ivy pastilles," Schweiz Zschr Ganzheitsmedizin, vol. 15, pp. 124-128, 2003 (German).

[31] S. Fazio, J. Pouso, D. Dolinsky et al., "Tolerance, safety and efficacy of Hedera helix extract in inflammatory bronchial diseases under clinical practice conditions: a prospective, open, multicentre postmarketing study in 9657 patients," Phytomedicine, vol. 16, no. 1, pp. 17-24, 2009.

[32] R. Gonzales and M. A. Sande, "Uncomplicated acute bronchitis," Annals of Internal Medicine, vol. 133, no. 12, pp. 981-991, 2000.

[33] A. D. Hay and A. D. Wilson, "The natural history of acute cough in children aged 0 to 4 years in primary care: a systematic review," British Journal of General Practice, vol. 52, no. 478, pp. 401-409, 2002.

[34] C. Özdemir, L. A. Schneider, R. Hinrichs et al., "Allergic contact dermatitis to common ivy (Hedera helix L.)," Hautarzt, vol. 54, no. 10, pp. 966-969, 2003 (German).

[35] J. M. Jones, I. R. White, J. M. L. White, and J. P. McFadden, "Allergic contact dermatitis to English ivy (Hedera helix)-a case series," Contact Dermatitis, vol. 60, no. 3, pp. 179-180, 2009.

[36] T. Hannu, P. Kauppi, M. Tuppurainen, and P. Piirilä, "Occupational asthma to ivy (Hedera helix)," Allergy, vol. 63, no. 4, pp. 482-483, 2008.

[37] J. Lexchin, L. A. Bero, B. Djulbegovic, and O. Clark, "Pharmaceutical industry sponsorship and research outcome and quality: systematic review," British Medical Journal, vol. 326, no. 7400, pp. 1167-1170, 2003.

[38] Y. C. M. Duijvestijn, N. Mourdi, J. Smucny, G. Pons, and M. Chalumeau, "Acetylcysteine and carbocysteine for acute upper and lower respiratory tract infections in paediatric patients without chronic broncho-pulmonary disease," Cochrane Database of Systematic Reviews, no. 1, Article ID CD003124, 2009.

[39] A. Altiner, S. Brockmann, M. Sielk, S. Wilm, K. Wegscheider, and H.-H. Abholz, "Reducing antibiotic prescriptions for acute cough by motivating GPs to change their attitudes to communication and empowering patients: a clusterrandomized intervention study," Journal of Antimicrobial Chemotherapy, vol. 60, no. 3, pp. 638-644, 2007. 


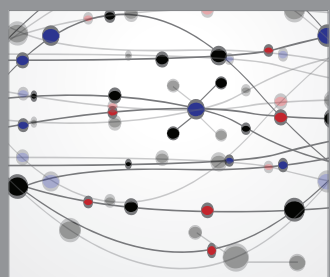

The Scientific World Journal
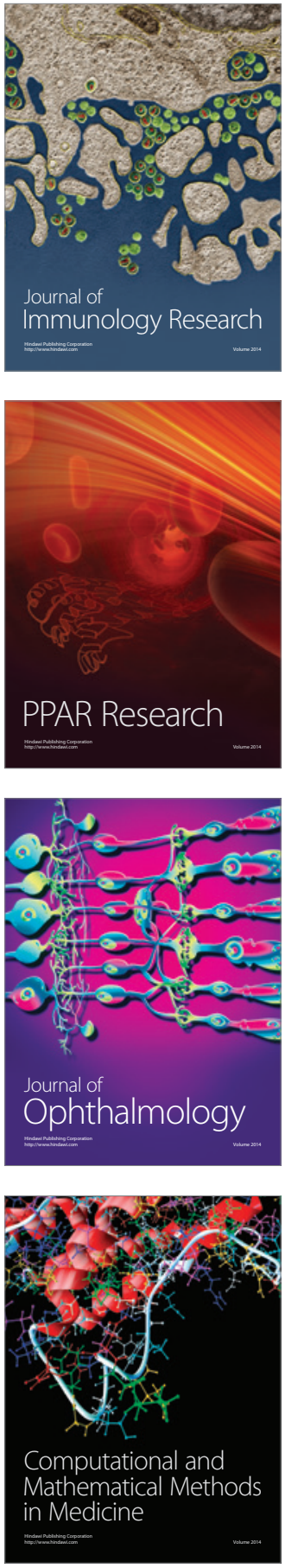

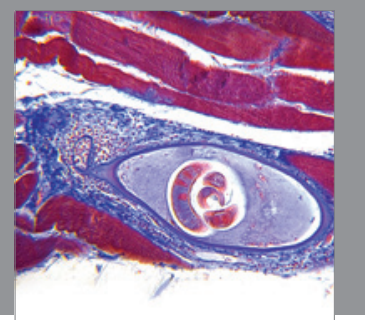

Gastroenterology

Research and Practice
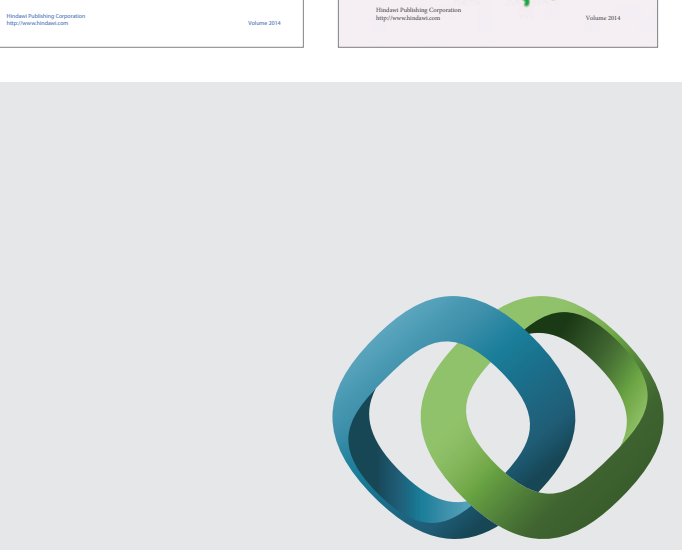

\section{Hindawi}

Submit your manuscripts at

http://www.hindawi.com
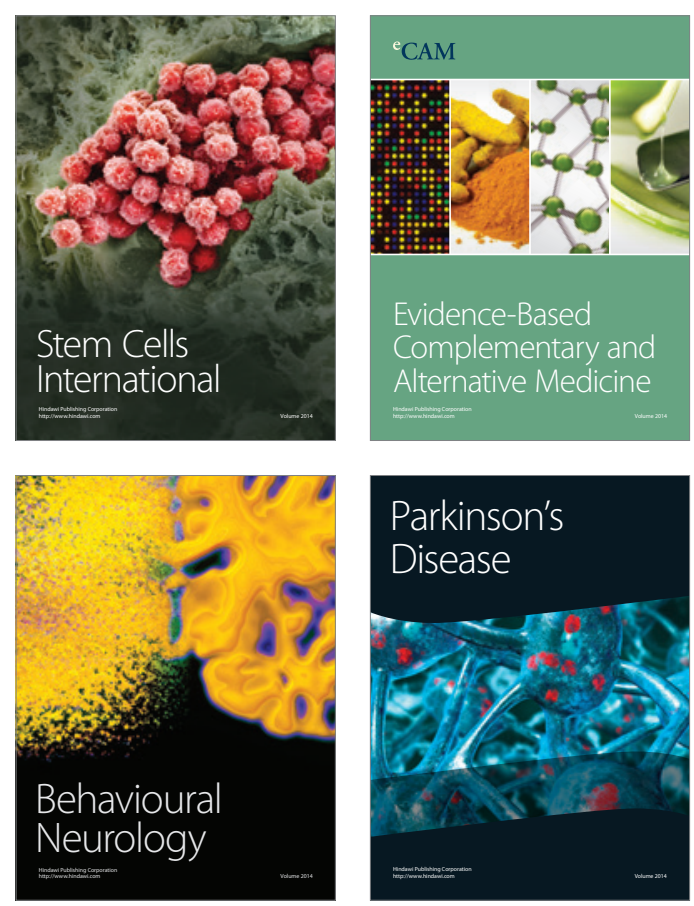

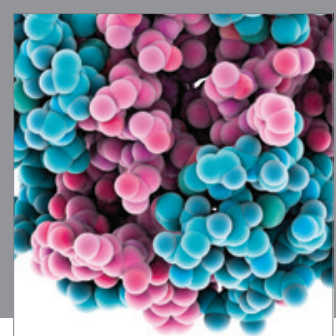

Journal of
Diabetes Research

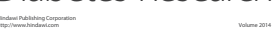

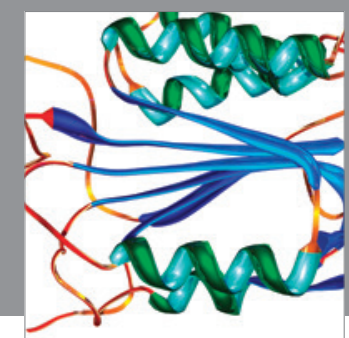

Disease Markers
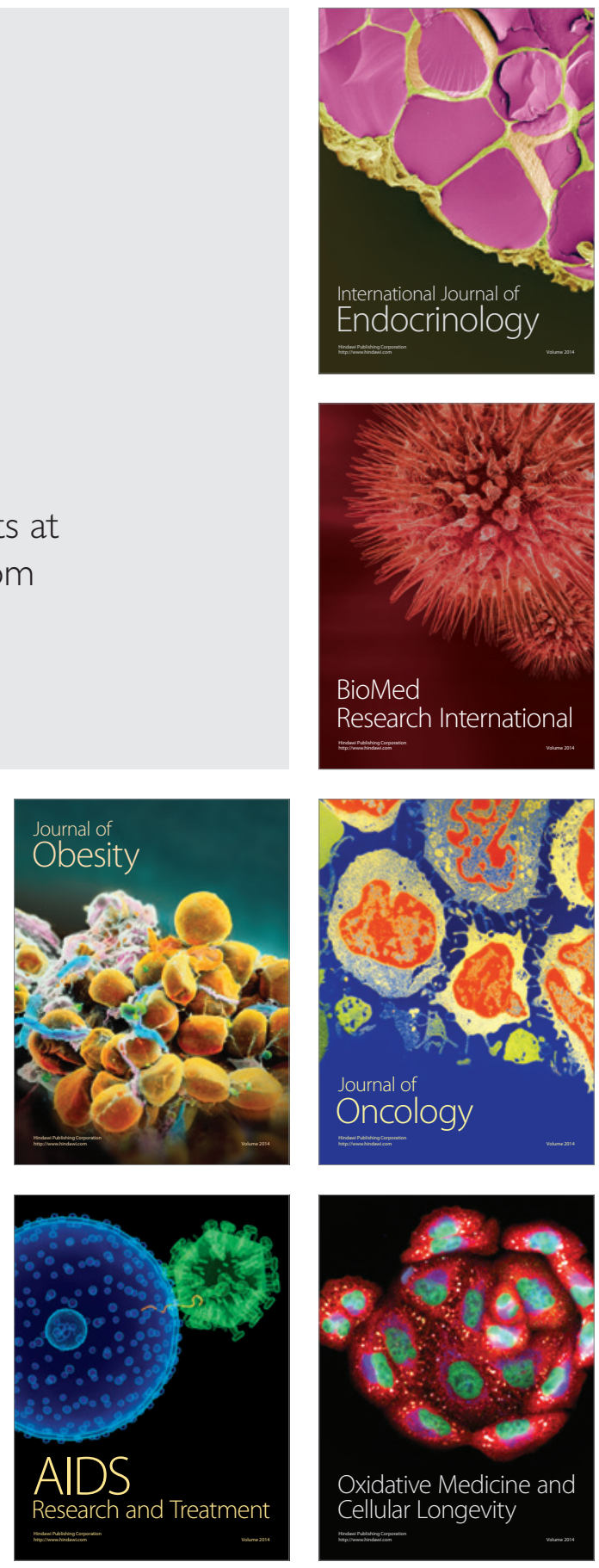